Article

\title{
Predictive Features of Malignancy in Branch Duct Type Intraductal Papillary Mucinous Neoplasm of the Pancreas: A Meta-Analysis
}

\author{
Wooil Kwon $^{\dagger}$, Youngmin Han ${ }^{\dagger}$, Yoonhyeong Byun ${ }^{\circledR}$, Jae Seung Kang ${ }^{\circledR}$, Yoo Jin Choi, \\ Hongbeom Kim and Jin-Young Jang * (D) \\ Department of Surgery and Cancer Research Institute, Seoul National University College of Medicine, \\ Seoul 03080, Korea; willdoc@snu.ac.kr (W.K.); views@snu.ac.kr (Y.H.); yoonhyeong@snu.ac.kr (Y.B.); \\ 74398@snuh.org (J.S.K.); 74401@snuh.org (Y.J.C.); surgeonkhb@snu.ac.kr (H.K.) \\ * Correspondence: jangjy4@snu.ac.kr; Tel.: +82-2-2072-2914; Fax: +82-2-766-3975 \\ + These authors contributed equally to this paper as first authors.
}

Received: 31 July 2020; Accepted: 11 September 2020; Published: 14 September 2020

Simple Summary: Currently, there are several guidelines that are widely used to establish the treatment strategy for branch duct type intraductal papillary mucinous neoplasms. Although there are some common grounds, there are discrepancies on which features they adopt, how much each feature is weighted, and how the features are combined. Furthermore, some of the features are based on lower level evidences or expert opinions. The aim of this meta-analysis was to investigate important clinical, radiological, and biochemical risk factors for malignancy and their impact as predictors. This study found symptom, size, cyst wall thickening, presence of mural nodule, change in main pancreatic duct caliber, lymphadenopathy, CA 19-9, and CEA as risk factors. Lymphadenopathy (odd ratio [OR]: 8.55), abrupt caliber change (OR: 7.41), and mural nodule (OR: 4.10) had the highest odd ratios. We expect the higher level evidences of this study to help shape better guidelines and reduce discrepancies among future guidelines.

Abstract: The current guidelines on branch duct type intraductal papillary mucinous neoplasm (BD-IPMN) recommend various predictive features of malignancy as well as different treatment strategies. This study aimed to identify the risk factors for malignancy with higher level of evidence. A meta-analysis was performed on 40 literatures published between 2000 and 2019. These literatures included 6301 patients with pathologically proven IPMN. Malignancy was defined as high-grade dysplasia and invasive carcinoma. It was significantly associated with symptoms (odds ratio [OR] 1.35, confidence interval [CI] 1.01-1.79), size $\geq 3 \mathrm{~cm}$ (OR 1.90, CI 1.51-2.40), cystic wall thickening (OR 2.53, CI 1.50-4.27), mural nodule (OR 4.10, CI 3.38-4.97), main pancreatic duct dilatation (OR 2.98, CI 2.11-4.21), abrupt caliber change of the pancreatic duct (OR 7.41, CI 2.49-22.06), lymphadenopathy (OR 8.55, CI 3.25-22.51), elevated carbohydrate antigen 19-9 (OR 4.01, CI 2.55-6.28), and elevated carcinoembryonic antigen (OR 2.04, CI 1.60-2.61). Multilocular cysts and multiple cysts did not show a significant association with malignancy. This study examined the clinical, radiological, and biochemical features of BD-IPMN, often used as malignancy predictors according to the widely used guidelines. The results confirmed that all the features currently being used are valid.

Keywords: branch duct intraductal papillary mucinous neoplasm; risk factor; malignancy; meta-analysis 


\section{Introduction}

Branch duct type intraductal papillary mucinous neoplasm (BD-IPMN) is a well-known premalignant lesion of the pancreas. The prevalence of BD-IPMN-associated malignancy is reportedly over $24 \%$ [1]. Nearly four decades have passed since the first report of IPMN by Ohashi et al. [2], but our understanding of IPMN is still limited. Particularly, the ability to predict malignancy and set an appropriate treatment plan is far from satisfactory. Given that pancreatic cancer is the fourth leading cause of cancer mortality [3], the clinical implications of this shortcoming are grave. To make matters worse, the incidence of IPMN is on a steady rise, as incidental detections are increasing due to better access to heath check-ups and increased use of cross-sectional imaging studies [4,5]. The current situation poses a great challenge for pancreatic surgeons and physicians.

Many investigations have been conducted, results have been produced, and the endeavor continues. Currently, there are several management guidelines for IPMN. Among them, the most frequently referenced are those by the American Gastroenterological Association (AGA) [6], European Study Group on Cystic Tumours of the Pancreas [7,8], and International Association of Pancreatology (IAP) $[1,9,10]$. Although all these guidelines have some commonalities, they do differ with respect to certain surgical treatment indications and surveillance strategies. Another issue is that few of these guidelines cite studies with lower levels of evidences, while others cite experts' opinions.

The first step in producing high-quality treatment guidelines for BD-IPMN is to clarify the risk factors for malignancy. Therefore, a meta-analysis was performed to identify the clinically important risk factors for malignancy and their impact. This study investigated the comprehensive factors including clinical, radiological, and biochemical factors that could be acquired preoperatively.

\section{Results}

\subsection{Search Results}

The search process is described in Figure 1. A thorough literature search on MEDLINE identified 472 publications that were potentially relevant to this study. A total of, 412 studies were excluded after screening. Of the remaining 60 publications, 17 were excluded after detailed review due to insufficient data regarding worrisome features/high-risk stigmata, absence of pathological data, insufficient sample size, or overlap with another study. When an overlapping study cohort was found, the larger sample study was chosen. If there were results regarding worrisome features/high-risk stigmata in a smaller overlapping study that was not addressed in the larger one, it was still included. Finally, 40 publications were included in the analysis [11-50]. The publication bias was assessed visually by inspecting the funnel plot for asymmetry.

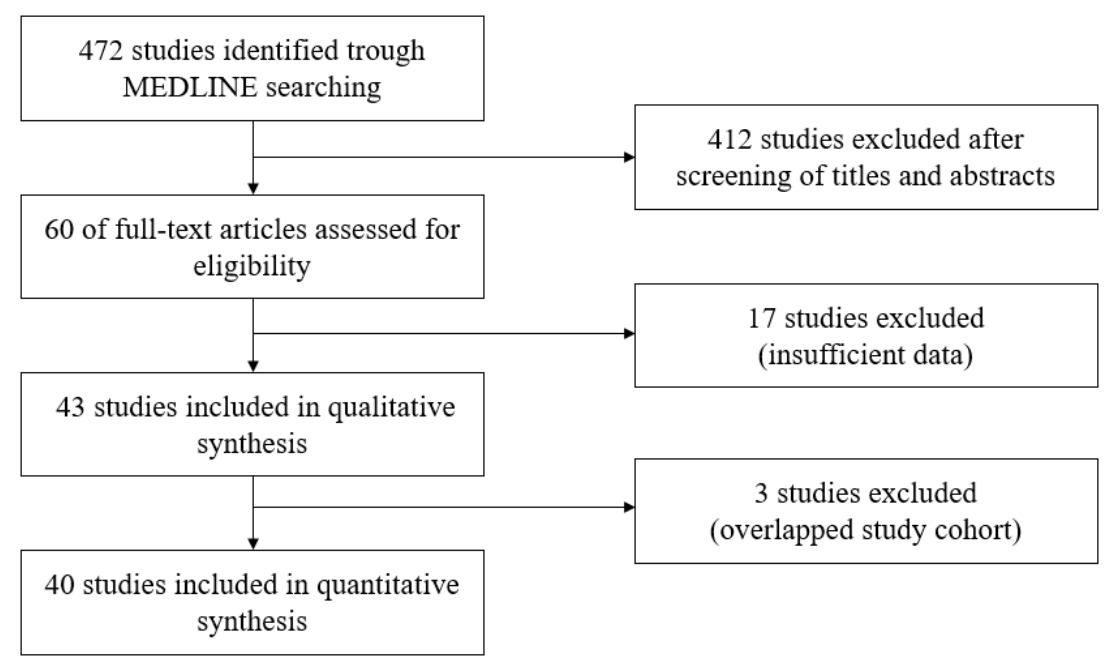

Figure 1. A flow diagram of the inclusion criteria of studies eligible for meta-analysis. 


\subsection{Characteristics of Included Studies}

The characteristics of the included publications are described in Table 1. This study included 40 publications with 6301 patients diagnosed with IPMN, of which histological data of 4241 patients diagnosed with benign IPMN and 2060 with malignant IPMN were identified. In all studies, malignant IPMN was defined as invasive carcinoma and high-grade dysplasia. Terms such as invasive cancer, intraductal papillary mucinous carcinoma (IPMC), and invasive IPMN were considered equivalent to invasive carcinoma. Non-invasive carcinoma, carcinoma in situ, and IPMC in situ were considered equivalent to high-grade dysplasia.

\subsection{Clinical Symptoms}

Data regarding symptoms were extractable in 15 studies $[12,15,19,20,23,25,27,31,33,35,36,38,40-42]$. In these studies, 840 patients (54.8\%) presented symptoms, and malignancy was reported in $28.6 \%$ of patients with symptoms and $27.4 \%$ without symptoms. The odds ratio (OR) of having symptoms was 1.35 (95\% confidence interval [CI] 1.01-1.79, $p=0.040$ ) (Table 2, Figure 2a).

\subsection{Characteristics of Cyst}

Data regarding cyst size were obtained from 22 studies with 4446 patients $[12,15-17,20-22,24-26$, 30-33,36-38,40,41,43,48,49], and the risk of malignancy was examined for a reference size of $3 \mathrm{~cm}$. The malignancy rate in cysts $\geq 3 \mathrm{~cm}$ and $<3 \mathrm{~cm}$ in size was $38.7 \%$ and $25.7 \%$, respectively. Cysts of size $\geq 3 \mathrm{~cm}$ significantly increased the risk of malignancy with an OR of 1.90 (95\% CI 1.51-2.40, $p<0.001$ ) (Table 2, Figure 2b).

Data regarding cystic wall thickening was extracted from nine studies with 689 patients $[13,14,17,18,34,37,38,40,43]$, and wall thickening was found in $15.2 \%$ of the cases. Moreover, $51.4 \%$ of the patients with wall thickening reported malignancy as compared to $23.6 \%$ of those without wall thickening. Wall thickening was significantly associated with malignancy with OR of 2.53 (95\% CI $1.50-4.27, p<0.001$ ) (Table 2, Figure 2c).

Multilocularity and multiplicity was analyzed in seven $[17,20,21,34,37,40,47]$ and eight studies $[12,15,17,21,35,37,40,47]$, respectively. Malignancy rate of multilocular and unilocular cysts was $27.0 \%$ and $22.2 \%$, respectively. Furthermore, the malignancy rate of single and multiple cysts was $26.6 \%$ and $24.0 \%$, respectively. Notably, neither of the features was associated with an increased risk of malignancy (multilocularity: OR $0.92,95 \%$ CI $0.63-1.35, p=0.680$; multiplicity: OR $0.76,95 \%$ CI $0.55-1.04, p=0.090$ ) (Table 2, Figure 2d,e). 
Table 1. Characteristics of included studies.

\begin{tabular}{|c|c|c|c|c|c|c|c|c|c|c|}
\hline Study & Year & $\begin{array}{l}\text { Study } \\
\text { Period }\end{array}$ & $\begin{array}{c}\text { No. of } \\
\text { Patients }\end{array}$ & Mean Age (Years) & Male/Female & Type of IPMN & Benign & Malignant & $\begin{array}{c}\text { Malignancy } \\
\text { Proportion (\%) }\end{array}$ & Diagnostic Modality \\
\hline Akahoshi et al. [11] & 2018 & 2006-2017 & 50 & 68 & $33 / 17$ & $\mathrm{BD}$ & 33 & 17 & $34.0 \%$ & $\mathrm{CT}, \mathrm{MRI}$ \\
\hline Akita et al. [12] & 2011 & $1992-2007$ & 32 & 62.6 & $19 / 13$ & $\mathrm{BD}$ & 20 & 12 & $37.5 \%$ & $\mathrm{CT}, \mathrm{MRI}, \mathrm{MRCP}$ \\
\hline Arikawa et al. [13] & 2011 & 2003-2008 & 25 & 65.2 & $20 / 5$ & $\mathrm{BD}$ & 17 & 8 & $32.0 \%$ & CT, MRCP, EUS \\
\hline Aso et al. [14] & 2014 & $2006-2013$ & 70 & N/A & N/A & $\mathrm{BD}$ & 42 & 28 & $40.0 \%$ & $\mathrm{CT}$, MRCP, EUS \\
\hline Attiyeh et al. [15] & 2018 & 2005-2015 & 381 & 67 & $160 / 221$ & $\mathrm{BD}$ & 276 & 105 & $27.6 \%$ & Not stated \\
\hline Bournet et al. [16] & 2009 & $1988-2005$ & 53 & 63.9 & $52 / 47$ & $\mathrm{BD}$, mixed & 29 & 24 & $24.2 \%$ & CT, MRCP, EUS, ERCP \\
\hline Carbognin et al. [17] & 2006 & 1995-2005 & 29 & $\begin{array}{c}\text { Benign } 64.7 \\
\text { Malignant } 62.2\end{array}$ & $17 / 12$ & $\mathrm{BD}$, mixed & 11 & 18 & $62.1 \%$ & $\mathrm{CT}, \mathrm{MRI}, \mathrm{MRCP}$ \\
\hline Chiu et al. [18] & 2006 & 1995-2005 & 40 & N/A & N/A & $\mathrm{BD}, \mathrm{MD}$, mixed & 30 & 10 & $25.0 \%$ & СТ \\
\hline Correa-Gallego et al. [19] & 2013 & 1994-2010 & 123 & 68 & $50 / 73$ & $\mathrm{BD}$ & 87 & 36 & $29.3 \%$ & Not stated \\
\hline Dortch et al. [20] & 2015 & 2002-2013 & 66 & 68 & $26 / 42$ & $\mathrm{BD}$ & 54 & 12 & $18.2 \%$ & CT, MRCP, EUS, FNA \\
\hline Fritz et al. [21] & 2014 & 2004-2012 & 233 & N/A & $95 / 138$ & $\mathrm{BD}$ & 177 & 56 & $24.0 \%$ & $\mathrm{CT}, \mathrm{MRI}$ \\
\hline Harima et al. [22] & 2015 & 2009-2014 & 15 & N/A & N/A & $\mathrm{BD}$ & 1 & 14 & $93.3 \%$ & $\mathrm{CT}, \mathrm{EUS}$ \\
\hline Hirono et al. [23] & 2017 & 1999-2015 & 109 & N/A & $46 / 63$ & $\mathrm{BD}$ & 52 & 57 & $52.3 \%$ & $\mathrm{CT}$, EUS \\
\hline Jang et al. [24] & 2017 & $1992-2012$ & 2258 & 65.0 & $1408 / 850$ & $\mathrm{BD}$ & 1429 & 829 & $36.7 \%$ & CT, EUS \\
\hline Kato et al. [25] & 2015 & 1994-2012 & 47 & 66.2 & $30 / 17$ & $\mathrm{BD}$ & 25 & 22 & $46.8 \%$ & Not stated \\
\hline Kim YI et al. [26] & 2015 & $1997-2013$ & 324 & 62 & $179 / 145$ & $\mathrm{BD}$ & 282 & 42 & $13.0 \%$ & $\mathrm{CT}$, MRCP, EUS, ERCP \\
\hline Kim TH et al. [27] & 2015 & 2004-2012 & 177 & 63 & $108 / 69$ & $\mathrm{BD}$ & 138 & 39 & $22.0 \%$ & CT, EUS \\
\hline Koshita et al. [28] & 2017 & 2005-2014 & 28 & 62.2 & $17 / 11$ & $\mathrm{BD}$ & 14 & 14 & $50.0 \%$ & CT, MRCP, EUS, ERCP \\
\hline Lee et al. [29] & 2014 & $2002-2011$ & 84 & 64.7 & $55 / 29$ & $\mathrm{BD}$ & 68 & 16 & $19.0 \%$ & EUS \\
\hline Maguchi et al. [30] & 2011 & $\mathrm{~N} / \mathrm{A}$ & 29 & N/A & N/A & $\mathrm{BD}$ & 20 & 9 & $31.0 \%$ & CT, EUS \\
\hline Mimura et al. [31] & 2010 & 1998-2009 & 43 & $\begin{array}{l}\text { Benign } 66.0 \\
\text { Malignant } 667\end{array}$ & $29 / 14$ & $\mathrm{BD}$, mixed & 23 & 20 & $46.5 \%$ & CT, EUS \\
\hline Nagai et al. [32] & 2009 & 1984-2007 & 84 & 63 & $48 / 36$ & $\mathrm{BD}$ & 47 & 37 & $44.0 \%$ & CT, ERCP, MRI, EUS \\
\hline Nguyen et al. [33] & 2015 & 1996-2012 & 66 & 69 & $26 / 42$ & $\mathrm{BD}$ & 51 & 15 & $22.7 \%$ & CT, MRI, EUS \\
\hline Ogawa et al. [34] & 2008 & 2000-2006 & 49 & 64.9 & $39 / 20$ & $\mathrm{BD}$ & 22 & 27 & $55.1 \%$ & CT \\
\hline Ohno et al. [35] & 2012 & $2001-2009$ & 30 & 65.1 & $15 / 15$ & $\mathrm{BD}$ & 19 & 11 & $63.3 \%$ & $\mathrm{CT}, \mathrm{ERCP}, \mathrm{CE}-\mathrm{EUS}$ \\
\hline Ohtsuka et al. [36] & 2012 & 1990-2009 & 99 & NA & $60 / 39$ & $\mathrm{BD}$ & 77 & 22 & $22.2 \%$ & $\mathrm{CT}, \mathrm{MRCP}, \mathrm{US}$, EUS \\
\hline Ridtitid et al. [37] & 2016 & 2001-2013 & 135 & 65.2 & $71 / 64$ & $\mathrm{BD}$ & 117 & 18 & $13.3 \%$ & CT, MRI, EUS \\
\hline Robles et al. [38] & 2016 & 2006-2014 & 120 & 57.9 & $65 / 55$ & $\mathrm{BD}$ & 84 & 36 & $30.0 \%$ & CT, MRI, EUS \\
\hline Rodriguez et al. [39] & 2007 & $1990-2005$ & 145 & $67^{*}$ & $62 / 83$ & $\mathrm{BD}$ & 113 & 32 & $22.1 \%$ & CEUS, CT, MRI \\
\hline Sahora et al. [40] & 2013 & $1995-2012$ & 217 & N/A & $82 / 135$ & $\mathrm{BD}$, mixed & 169 & 48 & $22.1 \%$ & $\mathrm{CT}$, MRI, MRCP, EUS \\
\hline Salvia et al. [41] & 2007 & 2000-2003 & 20 & 58 & $10 / 10$ & BD & 18 & 2 & $10.0 \%$ & US, MRI, MRCP, CEUS, EUS, ERCP \\
\hline Schmidt et al. [42] & 2007 & $1991-2006$ & 103 & 63 & $50 / 53$ & $\mathrm{BD}$ & 83 & 20 & $19.4 \%$ & CT, MRI, ERCP, EUS \\
\hline Seo et al. [43] & 2016 & 2011-2013 & 60 & 64.3 & $35 / 25$ & $\mathrm{BD}$ & 52 & 8 & $13.3 \%$ & $\mathrm{CT}$, MRI \\
\hline Serikawa et al. [44] & 2006 & 1992-2005 & 56 & 65.8 & $42 / 14$ & $\mathrm{BD}$ & 49 & 7 & $10.3 \%$ & US, EUS, CT, ERCP, MRCP \\
\hline Shimizu et al. [45] & 2020 & $1996-2014$ & 466 & 67.9 & $274 / 192$ & $\mathrm{BD}, \mathrm{MD}$, mixed & 208 & 258 & $55.4 \%$ & CT, EUS, MRCP \\
\hline Strauss et al. [46] & 2016 & 2004-2012 & 168 & N/A & $\mathrm{N} / \mathrm{A}$ & $\mathrm{BD}$ & 126 & 42 & $25.0 \%$ & $\mathrm{CT}$, MRI, MRCP \\
\hline Takeshita et al. [47] & 2008 & 2002-2006 & 46 & 65 & $28 / 25$ & $\mathrm{BD}$ & 38 & 8 & $17.4 \%$ & $\mathrm{CT}$ \\
\hline Tang et al. [48] & 2008 & 1995-2006 & 31 & 66.5 & $10 / 21$ & $\mathrm{BD}$ & 26 & 5 & $16.1 \%$ & CT, MRI, MRCP, ERCP, EUS \\
\hline Wong et al. [49] & 2013 & $2000-2010$ & 105 & 68 & $47 / 58$ & $\mathrm{BD}$ & 43 & 62 & $59.0 \%$ & CT, MRI, EUS \\
\hline Woo et al. [50] & 2009 & $1998-2005$ & 85 & 63 & $50 / 35$ & $\mathrm{BD}$ & 71 & 14 & $16.5 \%$ & CT, EUS, ERCP, MR \\
\hline
\end{tabular}

N/A, not available; IPMN, intraductal papillary mucinous neoplasm; BD, branch duct; MD, main duct; CT. computed tomography; MRI, magnetic resonance image; MRCP, magnetic resonance cholangiopancreatography; ERCP, endoscopic retrograde cholangiopancreatography; US, ultrasonography; CEUS, contrast-enhanced ultrasonography; EUS, endoscopic ultrasonography; CE-EUS, contrast-enhanced endoscopic ultrasonography; FNA, fine needle aspiration. * in median. 
Table 2. Summary of clinical, radiographic, and biochemical parameters.

\begin{tabular}{|c|c|c|c|c|c|c|c|c|c|}
\hline Parameters & No. Studies & No. of Patient & $\begin{array}{l}\text { No. of Positive } \\
\text { Feature (\%) }\end{array}$ & $\begin{array}{c}\text { No. of } \\
\text { Malignancy (\%) }\end{array}$ & $\begin{array}{l}\text { No. of Malignancy } \\
\text { among Positive } \\
\text { Features (\%) }\end{array}$ & $\begin{array}{l}\text { No. of Malignancy } \\
\text { among Negative } \\
\text { Features (\%) }\end{array}$ & OR & $95 \%$ CI & $p$-Value \\
\hline Symptoms (+) & 16 & 2844 & $1089(38.3)$ & $966(34.0)$ & $369(33.9)$ & $597(34.0)$ & 1.35 & $1.01,1.79$ & 0.040 \\
\hline Cyst size $(\geq 3 \mathrm{~cm})$ & 22 & 4446 & $2091(47.0)$ & $1414(31.8)$ & $814(38.9)$ & $605(25.7)$ & 1.90 & $1.51,2.40$ & $<0.001$ \\
\hline Wall thickening & 9 & 689 & $105(15.2)$ & $192(27.9)$ & 54 (51.4) & $138(23.6)$ & 2.53 & $1.50,4.27$ & $<0.001$ \\
\hline Multilocular & 7 & 741 & $389(52.5)$ & $183(24.7)$ & $105(27.0)$ & $78(22.2)$ & 0.92 & $0.63,1.35$ & 0.68 \\
\hline Multiplicity & 8 & 1058 & $350(33.1)$ & $272(25.7)$ & $84(24.0)$ & $188(26.6)$ & 0.76 & $0.55,1.04$ & 0.09 \\
\hline Mural nodule & 25 & 4495 & $1610(35.8)$ & 1434 (31.9) & $845(52.5)$ & $589(20.4)$ & 4.10 & $3.38,4.97$ & $<0.001$ \\
\hline MPD dilatation & 15 & 3499 & $1482(42.4)$ & $1190(34.0)$ & $698(47.1)$ & $492(24.4)$ & 2.98 & $2.11,4.21$ & $<0.001$ \\
\hline$>5 \mathrm{~mm}$ & 8 & 3098 & $1305(42.1)$ & $1031(33.3)$ & $607(46.5)$ & $424(23.6)$ & 2.85 & $1.90,4.26$ & $<0.001$ \\
\hline$>6 \mathrm{~mm}$ & 5 & 270 & $107(39.6)$ & $125(46.3)$ & $70(65.4)$ & $55(33.7)$ & 3.86 & $1.63,9.11$ & 0.002 \\
\hline$>7 \mathrm{~mm}$ & 2 & 131 & $70(53.4)$ & $72(55.0)$ & $21(30.0)$ & $13(21.3)$ & 2.69 & $0.42,17.16$ & 0.29 \\
\hline $\begin{array}{c}\text { Abrupt caliber } \\
\text { change }\end{array}$ & 4 & 467 & $34(7.3)$ & $74(15.8)$ & $18(52.9)$ & $56(12.9)$ & 7.41 & $2.49,22.06$ & $<0.001$ \\
\hline Lymphadenopathy & 4 & 390 & $70(17.9)$ & $70(17.9)$ & $14(20.0)$ & $56(15.3)$ & 8.55 & $3.25,22.51$ & $<0.001$ \\
\hline CA $19-9(>37 \mathrm{U} / \mathrm{mL})$ & 8 & 3279 & 477 (14.5) & $1073(32.7)$ & $295(61.8)$ & $778(27.8)$ & 4.01 & $2.55,6.28$ & $<0.001$ \\
\hline CEA $(>5 \mathrm{ng} / \mathrm{mL})$ & 4 & 2405 & $301(12.5)$ & $912(37.9)$ & $161(53.5)$ & $751(35.7)$ & 2.04 & $1.60,2.61$ & $<0.001$ \\
\hline
\end{tabular}

OR, odd ratio; CI, confidence interval; MPD, main pancreatic duct; $\mathrm{CA}$, carbohydrate antigen; CEA, carcinoembryonic antigen. 
(a)

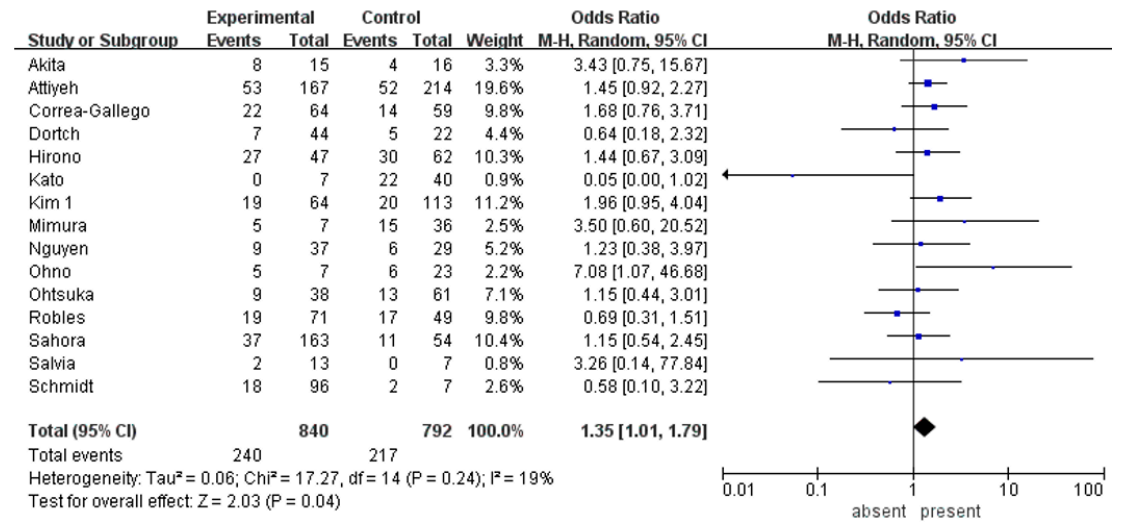

(b)

\begin{tabular}{llll} 
& \multicolumn{2}{l}{ Experimental Control } & Odds Ratio \\
Studv or Subgroup & Events Total Events Total Weight M.H. Random 95\%
\end{tabular} \begin{tabular}{lrrrrrr} 
Studv or Subgroup & Events & Total & Events & Total & Weight & M-H, Random, 95\% Cl \\
\hline Akita & 9 & 21 & 3 & 11 & $1.9 \%$ & $2.00[0.41,9.74]$
\end{tabular}

Attiyeh

$\begin{array}{llllll}\text { Boumet } & 12 & 16 & 12 & 37 & 2.7 \%\end{array}$

$\begin{array}{lllllll}\text { Carbognin } & 7 & 11 & 11 & 18 & 2.0 \%\end{array}$

Dortch

Fritz

Harima

Jang

Kato

Kim 1

Maguchi

Mimura

Nagai

Nguyen
Ohtsuka

Ohtsuka
Ridtitid

Robles

Sahora

Salvia

Seo

Tang

Wong

$\begin{array}{rrrr}11 & 11 & 18 & 2.0 \% \\ 18 & 6 & 48 & 2.8 \% \\ 47 & 43 & 186 & 7.0 \%\end{array}$

$\begin{array}{rrrrr}13 & 47 & 43 & 186 & 7.0 \% \\ 5 & 5 & 9 & 10 & 0.5 \%\end{array}$

$\begin{array}{rrrrr}5 & 5 & 9 & 10 & 0.5 \% \\ 518 & 1253 & 309 & 994 & 19.4 \%\end{array}$

$\begin{array}{rrr}09 & 994 & 19.4 \% \\ 8 & 20 & 3.3 \% \\ 13 & 174 & 7.4 \%\end{array}$

$\begin{array}{rrr}8 & 20 & 3.3 \% \\ 13 & 174 & 7.4 \%\end{array}$

$\begin{array}{rrrrr}9 & 150 & 13 & 174 & 7.4 \% \\ 5 & 16 & 4 & 13 & 2.0 \%\end{array}$

$\begin{array}{lll}4 & 13 & 2.0 \% \\ 7 & 12 & 2.6 \%\end{array}$

$\begin{array}{rrr}7 & 12 & 2.6 \% \\ 10 & 38 & 4.8 \%\end{array}$

\begin{tabular}{lll}
10 & 38 & $4.8 \%$ \\
10 & 50 & $2.9 \%$ \\
\hline & 34 & $2.8 \%$
\end{tabular}

$\begin{array}{rrr}3 & 34 & 2.8 \% \\ 13 & 97 & 3.6 \%\end{array}$

$\begin{array}{lll}13 & 97 & 3.6 \% \\ 20 & 77 & 6.0 \%\end{array}$

$\begin{array}{rrr}20 & 77 & 6.0 \% \\ 21 & 125 & 8.0 \%\end{array}$

$\begin{array}{lll}0 & 16 & 0.5 \%\end{array}$

$\begin{array}{lll}7 & 42 & 1.1 \%\end{array}$

Total $(95 \% \mathrm{Cl})$

Total events $\quad 809 \quad 605$

$\begin{array}{rrr}2 & 30 & 1.4 \% \\ 40 & 70 & 5.7 \%\end{array}$

Heterogeneity $\operatorname{Tau}^{2}=0.06 ; \mathrm{Ch}^{2}=29.27 \mathrm{df}=21(\mathrm{P}=0.11)^{\prime} \mathrm{I}^{2}=28 \%$

Test for overall effect: $Z=5.45$ ( $P<0.00001)$

$2.00[0.41,9.74]$

$6.25[1.66,23.50]$

$1.11[0.24,5.25]$

$3.50[0.95,12.85]$

$1.27[0.62,2.62]$

$1.74[0.06,50.43]$

$1.56[1.31,1.86]$

$1.56[1.31,1.86]$

$1.62[0.50,5.21]$

$2.97[1.48,5.95]$

$1.02[0.21,4.98]$

$0.52[0.13,1.99]$

$3.98[1.57,10.09]$

$1.82[0.51,6.44]$

$4.27[1.16,15.66]$

$0.98[0.32,2.96]$

$1.69[0.76,3.76]$

$2.06[1.07,3.94]$

$3.00[1.20,908.19]$

$0.29[0.03,2.59]$

$1.27[0.55,2.92]$

$1.90[1.51,2.40]$

(c)

$\begin{array}{ccc}\text { Yes } & \text { No } & \text { Odds Ratio } \\ \text { Studyor Subgroup } & \text { Events Total Events Total Weight M-H, Random.95\% }\end{array}$

Odds Ratio

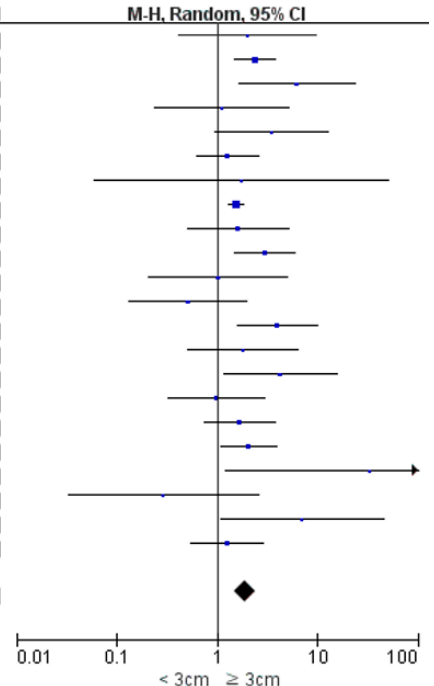

\begin{tabular}{lrrrrrr} 
Studv or Subgroup & Events & Total & Events & Total & Weight & M-H, Random, 95\% Cl \\
\hline Arikawa & 3 & 6 & 5 & 19 & $7.6 \%$ & $2.80[0.42,18.69]$
\end{tabular}

Carbognin

Carbog
Chiu

Chiu

Ogawa

Ridtitid

Robles

Saho

Seo

$\begin{array}{rrrrr}3 & 6 & 5 & 19 & 7.6 \% \\ 2 & 3 & 10 & 41 & 4.4 \%\end{array}$

$6.20[0.51,75.84]$

$9.37[0.47,188.21]$

$\begin{array}{rrrr}18 & 37 & 3.0 \% & 7.38[0.36,152.82] \\ 5 & 14 & 16.4 \% & 3.05[0.84,11.07]\end{array}$

$\begin{array}{rrrrr}32 & 35 & 5 & 14 & 16.4 \%\end{array}$

$\begin{array}{rrrrr}22 & 35 & 5 & 14 & 16.4 \% \\ 0 & 4 & 14 & 101 & 3.1 \%\end{array}$

$0.67[0.03,13.12]$

$2.83[1.16,6.88]$

$1.29[0.44,3.77]$

$3.57[0.29,44.72]$

Total $(95 \% \mathrm{Cl})$

$\begin{array}{lll}\text { Total events } & 54 & 138 \\ \text { Heterogeneity: } \operatorname{Tau}^{2}=0.00 ; \mathrm{Chi}^{2}=4.22, \mathrm{df}=8(\mathrm{P}=0.84) ; \mathrm{I}^{2}=0 \%\end{array}$

105

$\begin{array}{lll}4 & 198 \quad 23.7 \%\end{array}$

$2.53[1.50,4.27]$ Test for overall effect: $Z=3.48(P=0.0005)$

0.01

(d)

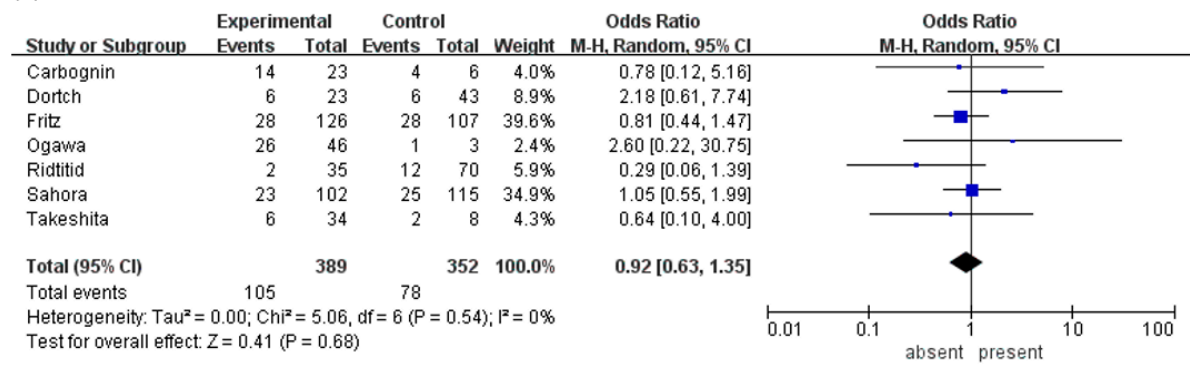

Figure 2. Cont. 
(e)

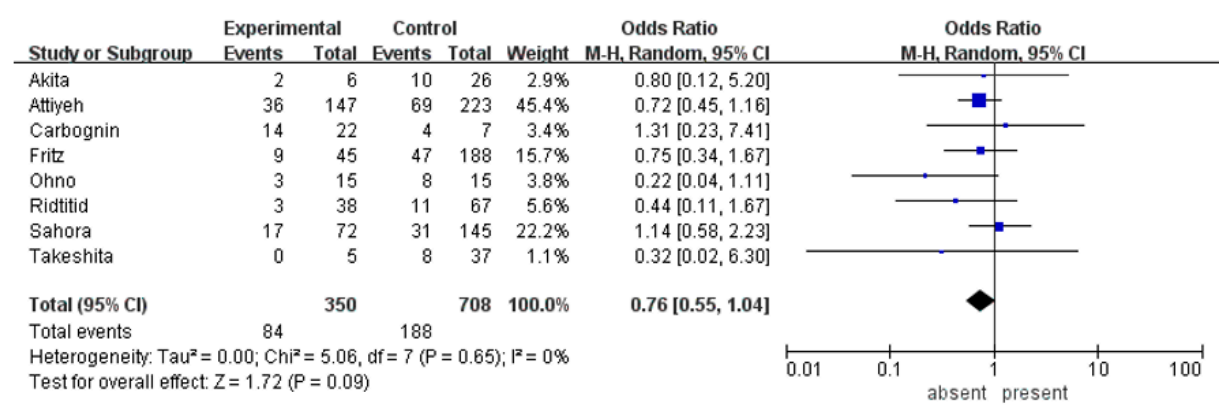

(f)

\begin{tabular}{|c|c|c|c|c|c|c|c|c|c|c|c|}
\hline Study or Subgroup & \multicolumn{2}{|c|}{ Experimental } & \multicolumn{2}{|c|}{ Control } & \multicolumn{2}{|c|}{$\begin{array}{c}\text { Odds Ratio } \\
\text { Weight } \mathrm{M}-\mathrm{H} \text {. Random, } 95 \% \mathrm{Cl}\end{array}$} & \multicolumn{5}{|c|}{$\begin{array}{c}\text { Odds Ratio } \\
\text { M-H, Random, } 95 \% \mathrm{Cl}\end{array}$} \\
\hline Akita & 10 & 13 & 2 & 19 & $1.0 \%$ & $28.33[4.02,199.60]$ & & & & & \\
\hline Arikawa & 5 & 8 & 3 & 17 & $1.0 \%$ & $7.78[1.17,51.91]$ & & & & & \\
\hline Bournet & 14 & 16 & 10 & 37 & $1.3 \%$ & $18.90[3.63,98.38]$ & & & & & ? \\
\hline Carbognin & 4 & 4 & 14 & 25 & $0.4 \%$ & $7.14[0.35,146.63]$ & & & & & \\
\hline Chiu & 7 & 11 & 14 & 29 & $1.8 \%$ & $1.88[0.45,7.82]$ & & & & & \\
\hline Correa-Gallego & 5 & 13 & 31 & 110 & $2.5 \%$ & $1.59[0.48,5.25]$ & & & & & \\
\hline Dortch & 5 & 17 & 7 & 49 & $2.1 \%$ & $2.50[0.67,9.31]$ & & & & & \\
\hline Fritz & 21 & 41 & 35 & 192 & $6.4 \%$ & $4.71[2.31,9.61]$ & & & & & \\
\hline Harima & 14 & 14 & 0 & 1 & $0.2 \%$ & $87.00[1.22,6192.44]$ & & & & & \\
\hline Hirono & 36 & 51 & 21 & 58 & $5.2 \%$ & $4.23[1.89,9.47]$ & & & & & \\
\hline Jang & 572 & 1066 & 257 & 1192 & $35.8 \%$ & $4.21[3.51,5.06]$ & & & & & 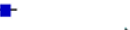 \\
\hline Kato & 12 & 15 & 9 & 32 & $1.6 \%$ & $10.22[2.32,44.97]$ & & & & & \\
\hline Kim 1 & 21 & 79 & 18 & 221 & $6.8 \%$ & $4.08[2.04,8.17]$ & & & & & \\
\hline Maguchi & 7 & 15 & 2 & 14 & $1.1 \%$ & $5.25[0.86,32.02]$ & & & & & \\
\hline Mimura & 9 & 17 & 11 & 26 & $2.4 \%$ & $1.53[0.45,5.25]$ & & & & & \\
\hline Nagai & 21 & 33 & 16 & 51 & $4.0 \%$ & $3.83[1.52,9.64]$ & & & & & \\
\hline Nguyen & 5 & 19 & 7 & 44 & $2.1 \%$ & $1.89[0.51,6.94]$ & & & & & \\
\hline Ohno & 5 & 11 & 6 & 19 & $1.5 \%$ & $1.81[0.39,8.35]$ & & & & & \\
\hline Ohtsuka & 16 & 41 & 6 & 58 & $3.2 \%$ & $5.55[1.94,15.89]$ & & & & & \\
\hline Robles & 10 & 17 & 26 & 103 & $3.1 \%$ & $4.23[1.46,12.25]$ & & & & & \\
\hline Sahora & 14 & 41 & 34 & 176 & $5.9 \%$ & $2.17[1.03,4.57]$ & & & & & \\
\hline Schmidt & 10 & 24 & 24 & 182 & $4.1 \%$ & $4.70[1.88,11.78]$ & & & & & \\
\hline Seo & 5 & 13 & 3 & 47 & $1.4 \%$ & $9.17[1.82,46.20]$ & & & & & \\
\hline Strauss & 12 & 21 & 30 & 147 & $3.8 \%$ & $5.20[2.01,13.48]$ & & & & & \\
\hline Takeshita & 5 & 10 & 3 & 36 & $1.2 \%$ & $11.00[1.98,60.99]$ & & & & & \\
\hline Total $(95 \% \mathrm{Cl})$ & & 1610 & & 2885 & $100.0 \%$ & $4.10[3.38,4.97]$ & & & & & 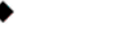 \\
\hline Total events & 845 & & 589 & & & & & & & & \\
\hline $\begin{array}{l}\text { Heterogeneity: Tauz } \\
\text { Test for overall effec }\end{array}$ & $\begin{array}{l}0.02 ; \mathrm{Chi} \\
\mathrm{Z}=14.32\end{array}$ & $\begin{array}{l}=26.09 \\
P<0.00\end{array}$ & $\begin{array}{l}d f=24 \\
001)\end{array}$ & $(P=0$. & $35) ; l^{2}=80$ & & 0.05 & 0.2 & absent & $\begin{array}{l}1 \\
\text { present }\end{array}$ & 20 \\
\hline
\end{tabular}

Figure 2. Forest plot showing the incidence of malignancy in BD-IPMN stratified by symptoms, characteristics of the cyst, and presence of mural nodule. (a) symptom. (b) cyst size. (c) cyst wall thickening. (d) multilocular cyst. (e) multiple cyst. and (f) mural nodule.

\subsection{Mural Nodule}

Mural nodule was the most frequently investigated parameter observed in 25 studies and cohort of 4495 patients $[12,13,16-26,30-33,35,36,38,40,42,43,46,47]$. The prevalence of mural nodule in BD-IPMN was $35.8 \%$, and the pooled malignancy rate was $31.9 \%$. The malignancy rate was $52.5 \%$ in the presence of mural nodule and $20.4 \%$ in its absence. The presence of mural nodule resulted in a four-fold increase in the malignancy risk. The pooled OR was 4.10 (95\% CI 3.38-4.97, $p<0.001)$ (Table 2, Figure 2f).

\subsection{Changes in Main Pancreatic Duct}

Several studies examined the size of the main pancreatic duct, but they all had different cut-off values. The reference size was $5 \mathrm{~mm}$ in eight studies [22,24-26,37,38,40,43], $6 \mathrm{~mm}$ in five studies [16,30-32,34], and $7 \mathrm{~mm}$ in two studies [12,36]. For pancreatic ducts of size $5 \mathrm{~mm}$, the OR was 2.85 (95\% CI 1.90-4.26, $p<0.001$ ), and a malignancy rate of $46.5 \%$ for ducts $>5 \mathrm{~mm}$. The ORs for main pancreatic ducts $>6$ and $7 \mathrm{~mm}$ were 3.86 (95\% CI 1.63-9.11, $p=0.002$ ) and 2.69 (95\% CI $0.42-17.16, p=0.29$ ), respectively. Overall, the OR for dilatation of the main pancreatic duct was 2.98 (95\% CI 2.11-4.21, $p<0.001$ ) (Table 2, Figure 3a). 
(a)

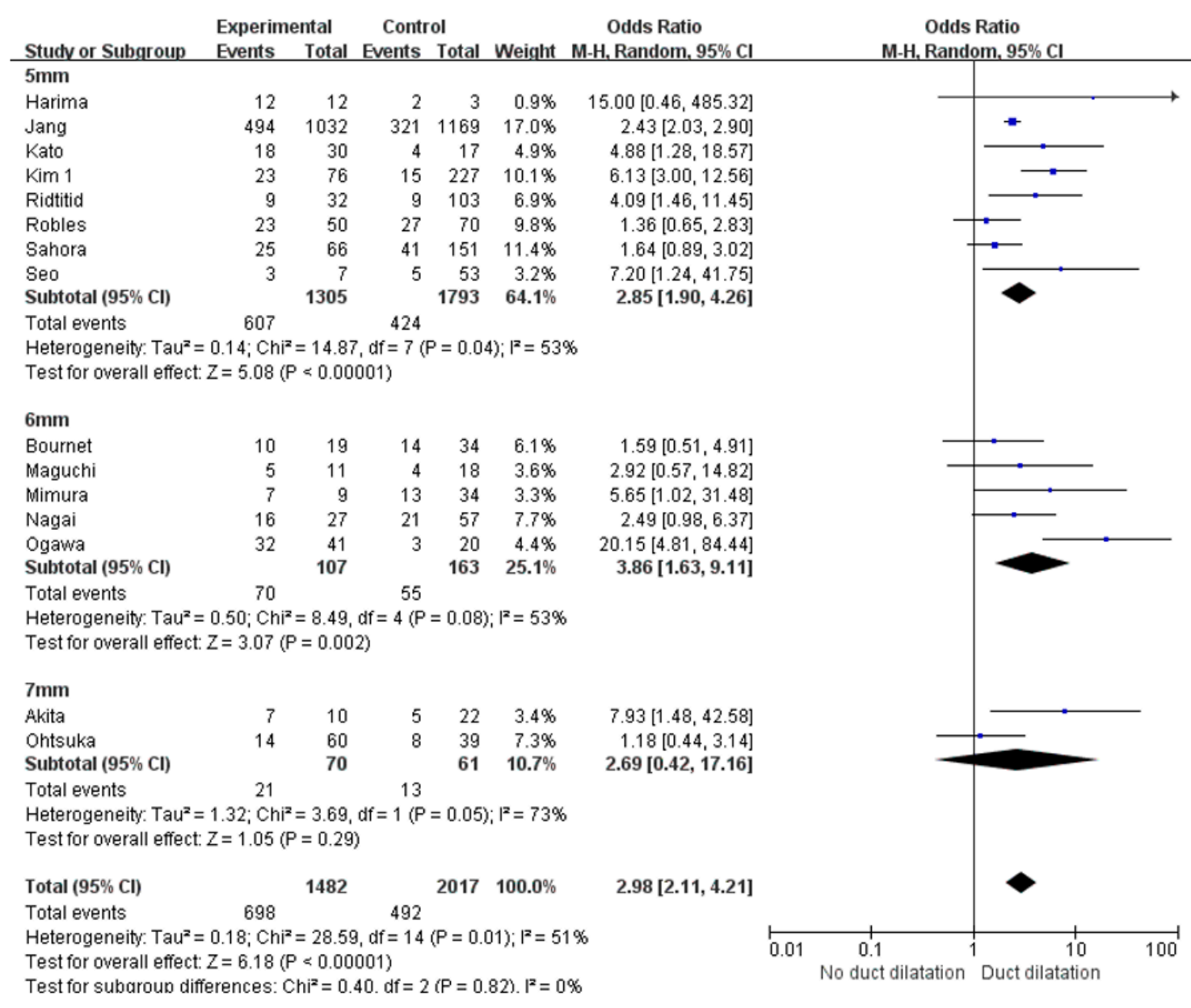

(b)

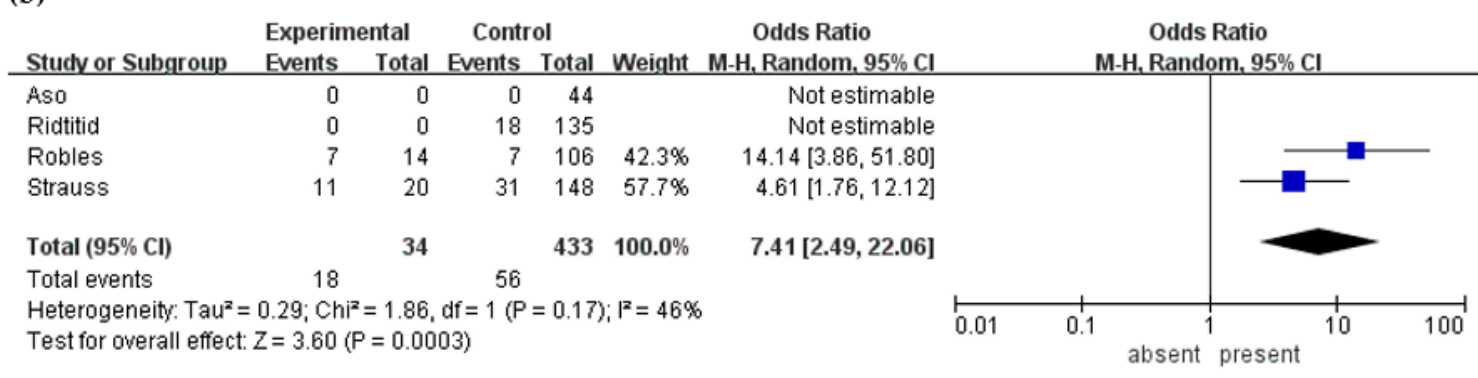

Figure 3. Forest plot demonstrates the incidence of malignancy in BD-IPMN in relation to change in main pancreatic duct. Forest plot stratified (a) by the diameter of pancreatic duct and (b) by abrupt caliber change.

Four studies examined the caliber change in the pancreatic duct in 467 patients $[14,37,38,46]$. Among 34 patients with an abrupt change in caliber, 18 patients (52.9\%) had malignant BD-IPMN with OR of 7.41 (95\% CI 2.49-22.06, $p<0.001$ ) (Table 2, Figure 3b).

\subsection{Lymphadenopathy}

Four studies examining lymphadenopathy had a pooled cohort of 390 patients $[14,17,21,43]$. The prevalence of lymphadenopathy was $6.2 \%$. The malignancy rate in these patients was $58.3 \%$ as compared to $15.3 \%$ in those without lymphadenopathy. The OR for lymphadenopathy was the highest among all parameters at 8.55 (95\% CI 3.25-22.51, $p<0.001)$ (Table 2, Figure 4). 


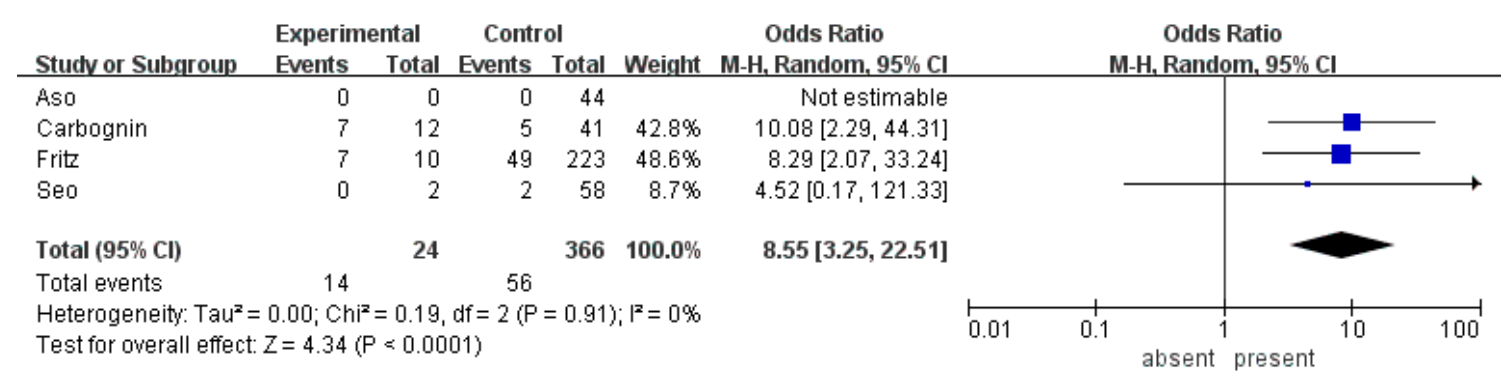

Figure 4. Forest plot demonstrates the incidence of malignancy in BD-IPMN stratified by the presence of lymphadenopathy.

\subsection{Biochemical Markers}

Carbohydrate antigen (CA) 19-9 with a cut-off level of $37 \mathrm{U} / \mathrm{mL}$ was examined in eight studies [15,21,23-26,36,40]. Among 3279 pooled patients, 477 patients $(14.5 \%)$ had elevated CA 19-9 levels, of which $61.8 \%$ had malignant BD-IPMN, whereas only $27.8 \%$ of the normal CA $19-9$ patients showed malignancy. The OR was 4.01 (95\% CI 2.55-6.28, $p<0.001)$ (Table 2 and Figure 5a).

(a)

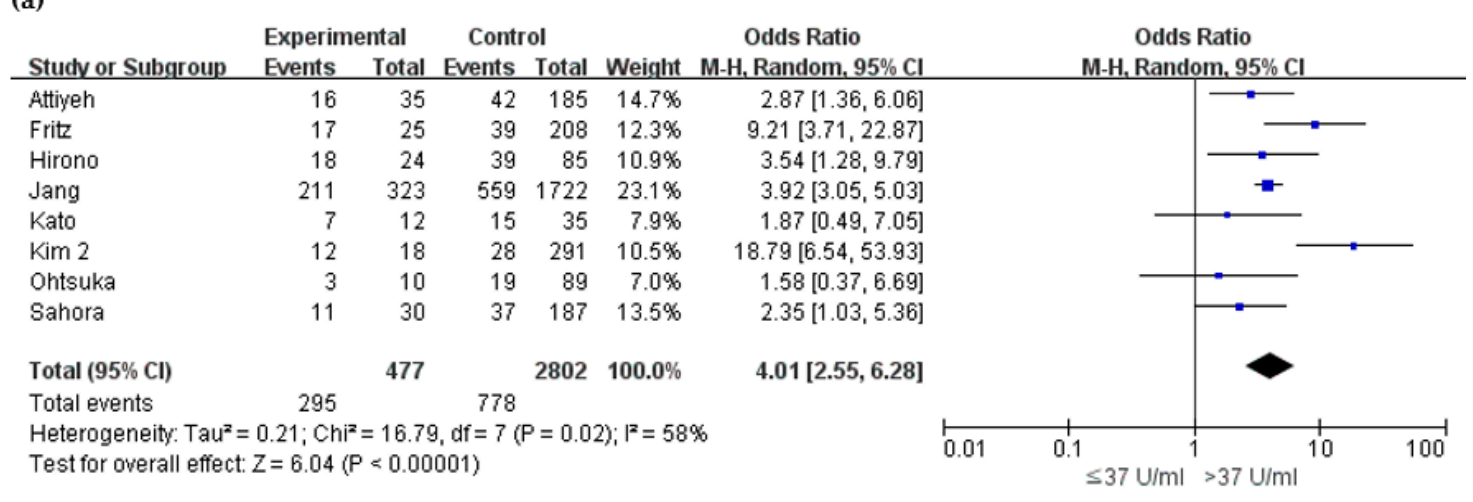

(b)

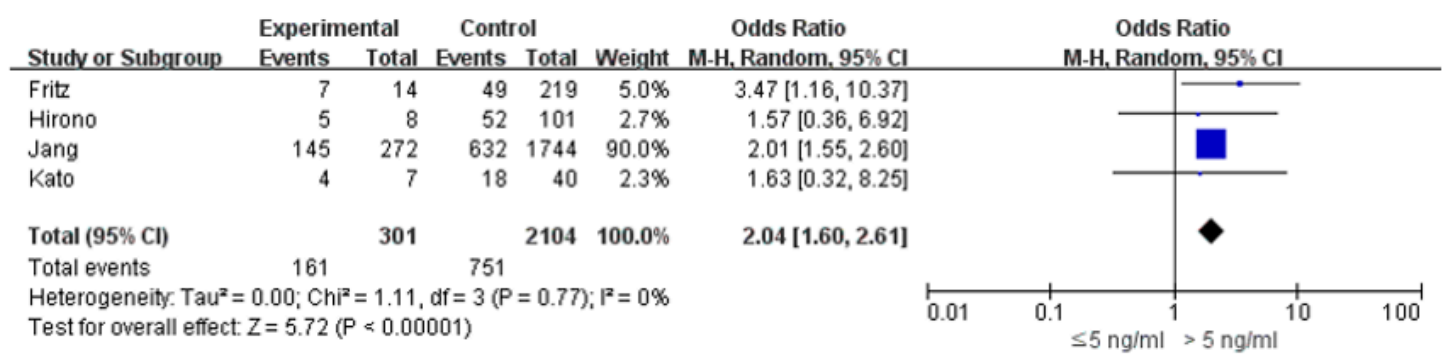

Figure 5. Forest plot demonstrates the incidence of malignancy in BD-IPMN in relation to biochemical markers. (a) carbohydrate antigen 19-9 and (b) carcinoembryonic antigen.

There were four studies [21,23-25] with pooled cohort of 2405 patients that reported the presence of carcinoembryonic antigen (CEA) with a cut-off level of $5 \mathrm{ng} / \mathrm{mL}$. The malignancy rate among patients with elevated CEA and normal CEA was $53.5 \%$ and $35.7 \%$, respectively. The OR for elevated CEA was 2.04 (95\% CI 1.60-2.61, $p<0.001)$ (Table 2, Figure 5b).

\section{Discussion}

This study revealed that the parameters of symptoms, size, cystic wall thickening, presence of mural nodule, change in main pancreatic duct caliber, lymphadenopathy, CA 19-9, and CEA were the predictive features of malignancy in BD-IPMN. On the other hand, multilocularity of cyst and multiple cysts were not malignancy predictors. 
The findings are in accordance with most of the widely used guidelines. The AGA guideline utilizes size, dilated main pancreatic duct, solid component, and positive cytology to determine the treatment strategy [6]. Reference size $\geq 3 \mathrm{~cm}$, dilated main pancreatic duct, and associated solid component were considered risk factors, and presence of at least two of these would warrant endoscopic ultrasound-fine needle aspiration (EUS-FNA). In the case of positive cytology or presence of a solid component and a dilated pancreatic duct, surgery is indicated. Since this guideline is for asymptomatic neoplastic pancreatic cysts, the symptoms were not considered.

Unlike the conservative AGA guidelines, the European study group proposes a more aggressive approach in BD-IPMN patients [7,8]. Presence of jaundice, positive cytology, enhancing mural nodule $(\geq 5 \mathrm{~mm}$ ), solid mass, and main pancreatic duct $\geq 10 \mathrm{~mm}$ are absolute indicators for surgery. Growth rate $\geq 5 \mathrm{~mm} /$ year, elevated serum CA 19-9 level, main pancreatic duct dilatation between 5-9.9 mm, cyst diameter $\geq 40 \mathrm{~mm}$, new onset diabetes mellitus, acute pancreatitis, and enhancing mural nodule $(<5 \mathrm{~mm})$ are relative indicators wherein healthy patients may opt for surgery.

The IAP guidelines stratify the features into high-risk stigmata and worrisome features. The high-risk stigmata and worrisome features warrant surgery and EUS, respectively. High-risk stigmata include obstructive jaundice in a patient with cystic lesion of the head of the pancreas, enhancing mural nodule $\geq 5 \mathrm{~mm}$, and main pancreatic duct $\geq 10 \mathrm{~mm}$. Worrisome features include cyst $\geq 3 \mathrm{~cm}$, enhancing mural nodule $<5 \mathrm{~mm}$, thickened/enhancing cyst walls, main duct size 5-9 mm, abrupt change in caliber of pancreatic duct with distal pancreatic atrophy, lymphadenopathy, increased CA 19-9 serum level, and cystic growth rate $\geq 5 \mathrm{~mm} / 2$ years. The features used by the IAP and European study group are similar. However, the IAP guidelines are slightly more conservative, wherein surgery is decided based on the EUS findings in patients with worrisome features.

In this study, all the features were included to validate those featuring in various guidelines. In addition, other features such as locularity, multiplicity, and CEA serum level were explored. The parameter of symptoms showed a significant association with malignancy. However, the symptoms could be heterogenous and often vague. They consisted of one or combinations of clinical findings such as abdominal pain, weight loss, pancreatitis, and jaundice. Therefore, it is difficult to define what symptom to look for and determine the appropriate treatment strategy. Notably, jaundice was found to be a significant predictor of malignancy by several studies $[15,27,38,42]$. In particular, a nomogram developed by Attiyeh et al. [15] automatically assigned a predicted probability of high-risk disease of " 1 " to patients with jaundice. Another symptom that showed high association with malignancy was weight loss. Among five studies that examined weight loss separately $[15,19,20,33,42]$, all studies except one [33] found weight loss to be significantly associated with malignancy. While many symptoms depend on the patient's report and tend to be subjective, jaundice and weight loss are symptoms that can be objectively quantified. Therefore, instead of considering symptoms as a whole, utilizing jaundice and weight loss to predict malignancy seemed reasonable, and studies defining the cut-off values for these symptoms should be warranted. Nevertheless, jaundice and weight loss are symptoms often associated with overt cancer and may have limited value in predicting earlier malignant transformation such as high-grade dysplasia. Our results showed that $27.4 \%$ of asymptomatic patients reported malignancy, demonstrating that absence of symptoms does not assure the absence of malignancy. Therefore, radiologic and biochemical changes may be more important in early detection of malignant transformations.

Previously, a cyst size of $3 \mathrm{~cm}$ was considered an absolute indication of BD-IPMN [10,51,52]. However, subsequent studies found that size alone was insufficient to predict malignancy, and although size correlated with malignancy risk, the safe cut-off limit was unclear [53-56]. The European study group does not consider a cyst size of $3 \mathrm{~cm}$ as an absolute indication, but rather considers the presence of other risk factors as determining factors, unless the diameter reaches $4 \mathrm{~cm}$ [7]. The IAP also stepped down the $3-\mathrm{cm}$ size criteria from an absolute indication to a worrisome feature since the 2012 consensus guidelines [1,9]. Likewise, although the AGA states that size $\geq 3 \mathrm{~cm}$ increases the risk of malignancy by three times [57], size is not the sole determinant of the strategy [6]. In the present study, size $\geq 3 \mathrm{~cm}$ 
increased the malignancy risk by two times. Although size is a significant factor, its impact is not as great as that of other features. Hence, size alone has a limited potential in predicting malignancy.

Wall thickening is a feature considered exclusively in the guidelines by IAP. It was introduced in the 2012 consensus guideline [1]. In this study, wall thickening increased the malignancy risk by 2.5 times. However, it is uncertain whether the wall thickening was accompanied by enhancement in the studies. Other cystic characteristics such as multilocularity or multiplicity of cysts did not increase the risk of malignancy.

Mural nodule is one of the strongest and most consistent risk factors in all the guidelines. Mural nodule is an absolute indication according to the European study group, and it could be an indication if it is accompanied by main pancreatic duct dilatation $>5 \mathrm{~mm}$ according to the AGA guidelines. The AGA found that solid component increased the risk by almost eight times after reviewing 816 patients in seven studies [57]. They found that the incidence of malignancy was $73 \%$ in patients with a mural nodule as compared to $23 \%$ in those without a mural nodule. In 25 studies with 4495 patients, the malignancy rate was $52.5 \%$ in those with a mural nodule and $20.4 \%$ in those without. Furthermore, this study found that the malignancy risk was four times higher in patients with mural nodule. Nevertheless, mural nodule is one of the highly predictive factors of malignancy. Recently, enhancement and size of mural nodule have received attention, and these factors were applied to the IAP and European study group guidelines $[1,8,58-61]$. However, the diagnostic performances vary according to the imaging modality used, and meta-analysis cannot be conducted with the limited number of studies. Therefore, this study did not sub-analyze the mural nodule feature by size or enhancement, and future studies are needed to clarify the effect of these factors.

The main pancreatic duct change is another consistent risk factor of malignancy. The European study group, AGA, and IAP guidelines include main pancreatic duct dilatation. The AGA did not provide a definition of main duct dilation, whereas the European study group and IAP defined duct dilatation as dilatation $>5 \mathrm{~mm}[1,6-9,57]$. The IAP and European study group further stratified the risk level according to the extent of dilatation. Main duct dilation between $5-9 \mathrm{~mm}$ and $>1 \mathrm{~cm}$ is considered as worrisome feature and high-risk stigmata by the IAP, or as a relative and absolute indication by the European study group. In contrast, the AGA requires that the solid component be accompanied by main duct dilatation for it to qualify as an indication. Interestingly, the AGA did not find a significant association between dilated pancreatic duct and malignancy (OR, 2.38, 95\% CI 0.71-8.00), but included it in their guidelines because the review was performed with resected IPMNs [6,57]. Nevertheless, the main duct dilatation is a well-recognized risk factor that was also confirmed in this meta-analysis. However, the reference cut-off values vary according to studies, and each guideline weighs the same criteria differently. Future efforts are required to reach a consensus. Another change often studied and considered in the IAP guidelines is the abrupt change in caliber. Although this may overlap with main duct dilatation and may be considered an extreme form of dilatation, its OR was the second highest in this study at 7.41. However, this was based only on four studies, and the true predictive value needs further validation.

Lymphadenopathy was recently added to the IAP guidelines during the 2017 revision [9]. There are no references to lymphadenopathy in the European study group or AGA guidelines. Although least attention was given to lymphadenopathy, it demonstrated the highest OR, showing 8.5 times increased risk of malignancy. There were only four studies with a pooled cohort of 390 patients, of which $6.2 \%$ had lymphadenopathy. More studies are needed to accurately evaluate the impact of lymphadenopathy in predicting the malignancy in BD-IPMN cases.

Finally, a biochemical marker, CA 19-9, was indicated as a relative risk factor in the European guidelines and as a worrisome feature in the revised 2017 IAP guidelines [7,9]. This study showed that elevated CA 19-9 above $37 \mathrm{U} / \mathrm{mL}$ had four times higher risk of malignancy, which is similar to the risk associated with mural nodule. In addition to CA 19-9, the role of CEA was examined, which posed twice the risk of malignancy when elevated above $5 \mathrm{ng} / \mathrm{mL}$. However, only four studies were examined and its actual role needs to be further studied for a definitive conclusion. 
There are several limitations in this study. First, all the studies included in this meta-analysis were observational studies, and potential biases are likely to be greater in such studies. Thus, the results should always be interpreted with caution. Second, the studies were conducted on resected IPMNs, thus limiting the knowledge regarding the natural course of the disease. Conversely, this ensures the most accurate pathologic diagnosis. Third, some features had slightly different or more specified definitions in the guidelines, e.g., for "enhanced" wall thickening, and different values for duct dilatations. However, for analysis with an adequate population, the features could not be too narrowly defined. Finally, as the risk of malignancy is likely to increase, an analysis of risk by combination of features or creating a predictive model would have been informative.

\section{Materials and Methods}

\subsection{Literature Search Strategy}

A literature search was conducted using the MEDLINE to identify a relevant study about the outcomes in patients with worrisome features or high-risk stigmata of IPMN and malignancy proven by surgery or biopsy. A combination of search terms, including IPMN, computed tomography (CT), magnetic resonance image (MRI), EUS, malignancy, worrisome features, or predictive features, were used.

\subsection{Inclusion/Exclusion Criteria}

Studies were included if they met the following criteria: written in English, full-article, publication year between January 2000 and May 2019, patient with BD-IPMN diagnosed by CT, MRI or EUS and final pathological diagnosis by surgical resection or biopsy, and $>10$ patients in the study. We excluded case reports, case series with small sample size ( $<10$ patients), review articles, editorials, consensus proceedings, studies without pathological diagnosis, not within field of interest, and insufficient or overlapping data.

\subsection{Data Extraction and Quality Assessment}

Two reviewers (W.K. and Y.H.) independently extracted the data from each study and resolved their disagreements by discussion or by consulting a third reviewer (J-Y.J.). The following data were collected from the studies that met the criteria. (1) Study-publication year, study design, and study location. (2) Cases-total number of BD-IPMN patients, frequency of pathologic malignancy in BD-IPMN, age, and sex. (3) Cystic morphology—maximum cyst size, presence of mural nodules, and maximum diameter of main pancreatic duct. (4) Clinical data-symptoms (jaundice, diabetes, pain, and weight loss), imaging methods, CA 19-9 level (normal value 0-37 U/mL), and CEA level (normal value $0-5 \mathrm{ng} / \mathrm{mL}$ ). (5) Outcomes-cytology result and pathology result.

Malignant BD-IPMN was identified when there was histological evidence of BD-IPMN with invasive carcinoma or high-grade dysplasia after surgical resection, and cytological/histological evidence of high-grade dysplasia/malignant cells was found after FNA/biopsy of BD-IPMN with or without associated radiological signs of malignancy.

The choice of the articles included in this review were in accordance with the Preferred Reporting Items for Systematic Reviews and Meta-Analyses statement (PRISMA) [62], and a PRISMA flowchart was formulated (Figure 1) for transparency of the conclusions reached by the authors. The quality of included studies was assessed using the Newcastle Ottawa Scale [63] by two reviewers (W.K. and Y.H.).

\subsection{Data Analysis}

Interpretative analysis of the OR between positive and negative worrisome features in IPMN patients was performed. The OR of BD-IPMN with or without worrisome features/high-risk stigmata was calculated by dividing the total number of events by the total number of patients. If these specific data were not provided in a study, it was calculated by adding or subtracting the number of 
patients who had confirmed pathology and imaging data. The corresponding 95\% CIs were calculated using exact methods. A meta-analysis of all eligible studies identified was then planned with the Review Manager software (RevMan) (version 5.3; The Cochrane Collaboration, The Nordic Cochrane Center, Copenhagen, Denmark) using a random-effects model. This model was used because we believe that the relevant variation in the risk is most likely a consequence of inter-study differences. Statistical analysis was performed for all stages of this meta-analysis in accordance with the MOOSE guidelines [64]. The quantity of heterogeneity and publication bias was assessed. A $p$-value $<0.050$ was accepted as statistically significant.

\section{Conclusions}

This study examined the parameters used to predict malignancy as specified by the most commonly used guidelines. This not only included clinical and radiographic features, but also biochemical features. The results confirmed that all the currently used features are valid. However, each guideline utilizes certain features and weighs the impact of each feature differently, resulting in different treatment strategies in BD-IPMN patients presenting similar features. This study hopes to contribute in making future guidelines more compatible and standardized.

Author Contributions: Conceptualization, W.K. and J.-Y.J.; methodology, Y.H., Y.B., J.S.K., Y.J.C.; software, Y.H.; validation, Y.H., W.K. and J.-Y.J.; formal analysis, Y.H. and W.K.; investigation, W.K. and J.-Y.J.; resources, H.K. and J.-Y.J.; data curation, Y.B., J.S.K., Y.J.C., Y.H., and H.K.; writing-original draft preparation, W.K. and Y.H.; writing-review and editing, W.K., Y.H., H.K., and J.-Y.J.; visualization, W.K. and Y.H.; supervision, J.-Y.J.; project administration, Y.H.; funding acquisition, J.-Y.J. All authors have read and agreed to the published version of the manuscript.

Funding: This study was supported by grant no. 23-2017-0090 from the SNUH Research Fund.

Conflicts of Interest: The authors declare no conflict of interest.

\section{References}

1. Tanaka, M.; Fernandez-del Castillo, C.; Adsay, V.; Chari, S.; Falconi, M.; Jang, J.Y.; Kimura, W.; Levy, P.; Pitman, M.B.; Schmidt, C.M.; et al. International consensus guidelines 2012 for the management of IPMN and MCN of the pancreas. Pancreatology 2012, 12, 183-197. [CrossRef]

2. Ohashi, K.; Murakami, Y.; Maruyama, M. Four cases of "mucin-producing" cancer of the pancreas on specific findings of the papilla of Vater. Prog. Dig. Endosc. 1982, 20, 348-352.

3. Siegel, R.L.; Miller, K.D.; Jemal, A. Cancer statistics, 2019. CA Cancer J. Clin. 2019, 69, 7-34. [CrossRef] [PubMed]

4. Chang, Y.R.; Park, J.K.; Jang, J.Y.; Kwon, W.; Yoon, J.H.; Kim, S.W. Incidental pancreatic cystic neoplasms in an asymptomatic healthy population of 21,745 individuals: Large-scale, single-center cohort study. Medicine (Baltimore) 2016, 95, e5535. [CrossRef] [PubMed]

5. Fernandez-del Castillo, C.; Targarona, J.; Thayer, S.P.; Rattner, D.W.; Brugge, W.R.; Warshaw, A.L. Incidental pancreatic cysts: Clinicopathologic characteristics and comparison with symptomatic patients. Arch. Surg. 2003, 138, 423-427. [CrossRef]

6. Vege, S.S.; Ziring, B.; Jain, R.; Moayyedi, P.; Clinical Guidelines, C.; American Gastroenterology, A. American gastroenterological association institute guideline on the diagnosis and management of asymptomatic neoplastic pancreatic cysts. Gastroenterology 2015, 148, 819-822, quize 812-813. [CrossRef]

7. Del Chiaro, M.; Verbeke, C.; Salvia, R.; Kloppel, G.; Werner, J.; McKay, C.; Friess, H.; Manfredi, R.; Van Cutsem, E.; Lohr, M.; et al. European experts consensus statement on cystic tumours of the pancreas. Dig. Liver Dis. 2013, 45, 703-711. [CrossRef] [PubMed]

8. European Study Group on Cystic Tumours of the Pancreas. European evidence-based guidelines on pancreatic cystic neoplasms. Gut 2018, 67, 789-804. [CrossRef] [PubMed]

9. Tanaka, M.; Fernandez-Del Castillo, C.; Kamisawa, T.; Jang, J.Y.; Levy, P.; Ohtsuka, T.; Salvia, R.; Shimizu, Y.; Tada, M.; Wolfgang, C.L. Revisions of international consensus Fukuoka guidelines for the management of IPMN of the pancreas. Pancreatology 2017, 17, 738-753. [CrossRef] [PubMed] 
10. Tanaka, M.; Chari, S.; Adsay, V.; Fernandez-del Castillo, C.; Falconi, M.; Shimizu, M.; Yamaguchi, K.; Yamao, K.; Matsuno, S. International consensus guidelines for management of intraductal papillary mucinous neoplasms and mucinous cystic neoplasms of the pancreas. Pancreatology 2006, 6, 17-32. [CrossRef] [PubMed]

11. Akahoshi, K.; Ono, H.; Akasu, M.; Ban, D.; Kudo, A.; Konta, A.; Tanaka, S.; Tanabe, M. Rapid growth speed of cysts can predict malignant intraductal mucinous papillary neoplasms. J. Surg. Res. 2018, 231, 195-200. [CrossRef] [PubMed]

12. Akita, H.; Takeda, Y.; Hoshino, H.; Wada, H.; Kobayashi, S.; Marubashi, S.; Eguchi, H.; Tanemura, M.; Mori, M.; Doki, Y.; et al. Mural nodule in branch duct-type intraductal papillary mucinous neoplasms of the pancreas is a marker of malignant transformation and indication for surgery. Am. J. Surg. 2011, 202, 214-219. [CrossRef] [PubMed]

13. Arikawa, S.; Uchida, M.; Uozumi, J.; Sakoda, J.; Kaida, H.; Kunou, Y.; Hirose, Y.; Abe, T.; Hayabuchi, N.; Naito, Y.; et al. Utility of multidetector row CT in diagnosing branch duct IPMNs of the pancreas compared with MR cholangiopancreatography and endoscopic ultrasonography. Kurume Med. J. 2011, 57, 91-100. [CrossRef] [PubMed]

14. Aso, T.; Ohtsuka, T.; Matsunaga, T.; Kimura, H.; Watanabe, Y.; Tamura, K.; Ideno, N.; Osoegawa, T.; Takahata, S.; Shindo, K.; et al. "High-risk stigmata" of the 2012 international consensus guidelines correlate with the malignant grade of branch duct intraductal papillary mucinous neoplasms of the pancreas. Pancreas 2014, 43, 1239-1243. [CrossRef] [PubMed]

15. Attiyeh, M.A.; Fernandez-Del Castillo, C.; Al Efishat, M.; Eaton, A.A.; Gonen, M.; Batts, R.; Pergolini, I.; Rezaee, N.; Lillemoe, K.D.; Ferrone, C.R.; et al. Development and Validation of a Multi-institutional Preoperative Nomogram for Predicting Grade of Dysplasia in Intraductal Papillary Mucinous Neoplasms (IPMNs) of the Pancreas: A Report from The Pancreatic Surgery Consortium. Ann. Surg. 2018, 267, 157-163. [CrossRef]

16. Bournet, B.; Kirzin, S.; Carrere, N.; Portier, G.; Otal, P.; Selves, J.; Musso, C.; Suc, B.; Moreau, J.; Fourtanier, G.; et al. Clinical fate of branch duct and mixed forms of intraductal papillary mucinous neoplasia of the pancreas. J. Gastroenterol. Hepatol. 2009, 24, 1211-1217. [CrossRef]

17. Carbognin, G.; Zamboni, G.; Pinali, L.; Chiara, E.D.; Girardi, V.; Salvia, R.; Mucelli, R.P. Branch duct IPMTs: Value of cross-sectional imaging in the assessment of biological behavior and follow-up. Abdom. Imaging 2006, 31, 320-325. [CrossRef]

18. Chiu, S.S.; Lim, J.H.; Lee, W.J.; Chang, K.T.; Oh, D.K.; Lee, K.T.; Lee, J.K.; Choi, S.H. Intraductal papillary mucinous tumour of the pancreas: Differentiation of malignancy and benignancy by CT. Clin. Radiol. 2006, 61, 776-783. [CrossRef]

19. Correa-Gallego, C.; Do, R.; Lafemina, J.; Gonen, M.; D'Angelica, M.I.; DeMatteo, R.P.; Fong, Y.; Kingham, T.P.; Brennan, M.F.; Jarnagin, W.R.; et al. Predicting dysplasia and invasive carcinoma in intraductal papillary mucinous neoplasms of the pancreas: Development of a preoperative nomogram. Ann. Surg. Oncol. 2013, 20, 4348-4355. [CrossRef]

20. Dortch, J.D.; Stauffer, J.A.; Asbun, H.J. Pancreatic Resection for Side-Branch Intraductal Papillary Mucinous Neoplasm (SB-IPMN): A Contemporary Single-Institution Experience. J. Gastrointest. Surg. 2015, 19, 1603-1609. [CrossRef]

21. Fritz, S.; Klauss, M.; Bergmann, F.; Strobel, O.; Schneider, L.; Werner, J.; Hackert, T.; Buchler, M.W. Pancreatic main-duct involvement in branch-duct IPMNs: An underestimated risk. Ann. Surg. 2014, 260, 848-855. [CrossRef]

22. Harima, H.; Kaino, S.; Shinoda, S.; Kawano, M.; Suenaga, S.; Sakaida, I. Differential diagnosis of benign and malignant branch duct intraductal papillary mucinous neoplasm using contrast-enhanced endoscopic ultrasonography. World J. Gastroenterol. 2015, 21, 6252-6260. [CrossRef]

23. Hirono, S.; Kawai, M.; Okada, K.I.; Miyazawa, M.; Shimizu, A.; Kitahata, Y.; Ueno, M.; Yanagisawa, A.; Yamaue, H. Factors Associated With Invasive Intraductal Papillary Mucinous Carcinoma of the Pancreas. JAMA Surg. 2017, 152, e165054. [CrossRef] [PubMed]

24. Jang, J.Y.; Park, T.; Lee, S.; Kim, Y.; Lee, S.Y.; Kim, S.W.; Kim, S.C.; Song, K.B.; Yamamoto, M.; Hatori, T.; et al. Proposed Nomogram Predicting the Individual Risk of Malignancy in the Patients with Branch Duct Type Intraductal Papillary Mucinous Neoplasms of the Pancreas. Ann. Surg. 2017, 266, 1062-1068. [CrossRef] [PubMed] 
25. Kato, Y.; Takahashi, S.; Gotohda, N.; Konishi, M. Risk factors for malignancy in branched-type intraductal papillary mucinous neoplasms of the pancreas during the follow-up period. World J. Surg. 2015, 39, $244-250$. [CrossRef] [PubMed]

26. Kim, Y.I.; Shin, S.H.; Song, K.B.; Hwang, D.W.; Lee, J.H.; Park, K.M.; Lee, Y.J.; Kim, S.C. Branch duct intraductal papillary mucinous neoplasm of the pancreas: Single-center experience with 324 patients who underwent surgical resection. Korean J. Hepatobiliary Pancreat. Surg. 2015, 19, 113-120. [CrossRef]

27. Kim, T.H.; Song, T.J.; Hwang, J.H.; Yoo, K.S.; Lee, W.J.; Lee, K.H.; Dong, S.H.; Park, C.H.; Park, E.T.; Moon, J.H.; et al. Predictors of malignancy in pure branch duct type intraductal papillary mucinous neoplasm of the pancreas: A nationwide multicenter study. Pancreatology 2015, 15, 405-410. [CrossRef]

28. Koshita, S.; Noda, Y.; Ito, K.; Kanno, Y.; Ogawa, T.; Masu, K.; Masaki, Y.; Horaguchi, J.; Oikawa, M.; Tsuchiya, T.; et al. Pancreatic juice cytology with immunohistochemistry to detect malignancy and histologic subtypes in patients with branch duct type intraductal papillary mucinous neoplasms of the pancreas. Gastrointest. Endosc. 2017, 85, 1036-1046. [CrossRef]

29. Lee, K.H.; Lee, S.J.; Lee, J.K.; Ryu, J.K.; Kim, E.Y.; Kim, T.H.; Moon, J.H.; Lee, W.J.; Cho, Y.K.; Kim, J.J. Prediction of malignancy with endoscopic ultrasonography in patients with branch duct-type intraductal papillary mucinous neoplasm. Pancreas 2014, 43, 1306-1311. [CrossRef]

30. Maguchi, H.; Tanno, S.; Mizuno, N.; Hanada, K.; Kobayashi, G.; Hatori, T.; Sadakari, Y.; Yamaguchi, T.; Tobita, K.; Doi, R.; et al. Natural history of branch duct intraductal papillary mucinous neoplasms of the pancreas: A multicenter study in Japan. Pancreas 2011, 40, 364-370. [CrossRef]

31. Mimura, T.; Masuda, A.; Matsumoto, I.; Shiomi, H.; Yoshida, S.; Sugimoto, M.; Sanuki, T.; Yoshida, M.; Fujita, T.; Kutsumi, H.; et al. Predictors of malignant intraductal papillary mucinous neoplasm of the pancreas. J. Clin. Gastroenterol. 2010, 44, e224-e229. [CrossRef] [PubMed]

32. Nagai, K.; Doi, R.; Ito, T.; Kida, A.; Koizumi, M.; Masui, T.; Kawaguchi, Y.; Ogawa, K.; Uemoto, S. Single-institution validation of the international consensus guidelines for treatment of branch duct intraductal papillary mucinous neoplasms of the pancreas. J. Hepatobiliary Pancreat. Surg. 2009, 16, 353-358. [CrossRef] [PubMed]

33. Nguyen, A.H.; Toste, P.A.; Farrell, J.J.; Clerkin, B.M.; Williams, J.; Muthusamy, V.R.; Watson, R.R.; Tomlinson, J.S.; Hines, O.J.; Reber, H.A.; et al. Current recommendations for surveillance and surgery of intraductal papillary mucinous neoplasms may overlook some patients with cancer. J. Gastrointest. Surg. 2015, 19, 258-265. [CrossRef] [PubMed]

34. Ogawa, H.; Itoh, S.; Ikeda, M.; Suzuki, K.; Naganawa, S. Intraductal papillary mucinous neoplasm of the pancreas: Assessment of the likelihood of invasiveness with multisection CT. Radiology 2008, 248, 876-886. [CrossRef]

35. Ohno, E.; Itoh, A.; Kawashima, H.; Ishikawa, T.; Matsubara, H.; Itoh, Y.; Nakamura, Y.; Hiramatsu, T.; Nakamura, M.; Miyahara, R.; et al. Malignant transformation of branch duct-type intraductal papillary mucinous neoplasms of the pancreas based on contrast-enhanced endoscopic ultrasonography morphological changes: Focus on malignant transformation of intraductal papillary mucinous neoplasm itself. Pancreas 2012, 41, 855-862. [PubMed]

36. Ohtsuka, T.; Kono, H.; Nagayoshi, Y.; Mori, Y.; Tsutsumi, K.; Sadakari, Y.; Takahata, S.; Morimatsu, K.; Aishima, S.; Igarashi, H.; et al. An increase in the number of predictive factors augments the likelihood of malignancy in branch duct intraductal papillary mucinous neoplasm of the pancreas. Surgery 2012, 151, 76-83. [CrossRef]

37. Ridtitid, W.; DeWitt, J.M.; Schmidt, C.M.; Roch, A.; Stuart, J.S.; Sherman, S.; Al-Haddad, M.A. Management of branch-duct intraductal papillary mucinous neoplasms: A large single-center study to assess predictors of malignancy and long-term outcomes. Gastrointest. Endosc. 2016, 84, 436-445. [CrossRef]

38. Robles, E.P.; Maire, F.; Cros, J.; Vullierme, M.P.; Rebours, V.; Sauvanet, A.; Aubert, A.; Dokmak, S.; Levy, P.; Ruszniewski, P. Accuracy of 2012 International Consensus Guidelines for the prediction of malignancy of branch-duct intraductal papillary mucinous neoplasms of the pancreas. United Eur. Gastroenterol. J. 2016, 4, 580-586. [CrossRef]

39. Rodriguez, J.R.; Salvia, R.; Crippa, S.; Warshaw, A.L.; Bassi, C.; Falconi, M.; Thayer, S.P.; Lauwers, G.Y.; Capelli, P.; Mino-Kenudson, M.; et al. Branch-duct intraductal papillary mucinous neoplasms: Observations in 145 patients who underwent resection. Gastroenterology 2007, 133, 72-79, quize 309-310. [CrossRef] 
40. Sahora, K.; Mino-Kenudson, M.; Brugge, W.; Thayer, S.P.; Ferrone, C.R.; Sahani, D.; Pitman, M.B.; Warshaw, A.L.; Lillemoe, K.D.; Fernandez-del Castillo, C.F. Branch duct intraductal papillary mucinous neoplasms: Does cyst size change the tip of the scale? A critical analysis of the revised international consensus guidelines in a large single-institutional series. Ann. Surg. 2013, 258, 466-475. [CrossRef]

41. Salvia, R.; Crippa, S.; Falconi, M.; Bassi, C.; Guarise, A.; Scarpa, A.; Pederzoli, P. Branch-duct intraductal papillary mucinous neoplasms of the pancreas: To operate or not to operate? Gut 2007, 56, 1086-1090. [CrossRef] [PubMed]

42. Schmidt, C.M.; White, P.B.; Waters, J.A.; Yiannoutsos, C.T.; Cummings, O.W.; Baker, M.; Howard, T.J.; Zyromski, N.J.; Nakeeb, A.; DeWitt, J.M.; et al. Intraductal papillary mucinous neoplasms: Predictors of malignant and invasive pathology. Ann. Surg. 2007, 246, 644-651. [CrossRef] [PubMed]

43. Seo, N.; Byun, J.H.; Kim, J.H.; Kim, H.J.; Lee, S.S.; Song, K.B.; Kim, S.C.; Han, D.J.; Hong, S.M.; Lee, M.G. Validation of the 2012 International Consensus Guidelines Using Computed Tomography and Magnetic Resonance Imaging: Branch Duct and Main Duct Intraductal Papillary Mucinous Neoplasms of the Pancreas. Ann. Surg. 2016, 263, 557-564. [CrossRef] [PubMed]

44. Serikawa, M.; Sasaki, T.; Fujimoto, Y.; Kuwahara, K.; Chayama, K. Management of intraductal papillary-mucinous neoplasm of the pancreas: Treatment strategy based on morphologic classification. J. Clin. Gastroenterol. 2006, 40, 856-862. [CrossRef]

45. Shimizu, Y.; Hijioka, S.; Hirono, S.; Kin, T.; Ohtsuka, T.; Kanno, A.; Koshita, S.; Hanada, K.; Kitano, M.; Inoue, H.; et al. New Model for Predicting Malignancy in Patients with Intraductal Papillary Mucinous Neoplasm. Ann. Surg. 2020, 272, 155-162. [CrossRef]

46. Strauss, A.; Birdsey, M.; Fritz, S.; Schwarz-Bundy, B.D.; Bergmann, F.; Hackert, T.; Kauczor, H.U.; Grenacher, L.; Klauss, M. Intraductal papillary mucinous neoplasms of the pancreas: Radiological predictors of malignant transformation and the introduction of bile duct dilation to current guidelines. Br. J. Radiol. 2016, 89, 20150853. [CrossRef]

47. Takeshita, K.; Kutomi, K.; Takada, K.; Haruyama, T.; Fukushima, J.; Aida, R.; Takada, T.; Furui, S. Differential diagnosis of benign or malignant intraductal papillary mucinous neoplasm of the pancreas by multidetector row helical computed tomography: Evaluation of predictive factors by logistic regression analysis. J. Comput. Assist. Tomogr. 2008, 32, 191-197. [CrossRef]

48. Tang, R.S.; Weinberg, B.; Dawson, D.W.; Reber, H.; Hines, O.J.; Tomlinson, J.S.; Chaudhari, V.; Raman, S.; Farrell, J.J. Evaluation of the guidelines for management of pancreatic branch-duct intraductal papillary mucinous neoplasm. Clin. Gastroenterol. Hepatol. 2008, 6, 815-819, quiz 719. [CrossRef]

49. Wong, J.; Weber, J.; Centeno, B.A.; Vignesh, S.; Harris, C.L.; Klapman, J.B.; Hodul, P. High-grade dysplasia and adenocarcinoma are frequent in side-branch intraductal papillary mucinous neoplasm measuring less than $3 \mathrm{~cm}$ on endoscopic ultrasound. J. Gastrointest. Surg. 2013, 17, 78-84. [CrossRef]

50. Woo, S.M.; Ryu, J.K.; Lee, S.H.; Yoon, W.J.; Kim, Y.T.; Yoon, Y.B. Branch duct intraductal papillary mucinous neoplasms in a retrospective series of 190 patients. Br. J. Surg. 2009, 96, 405-411. [CrossRef]

51. Matsumoto, T.; Aramaki, M.; Yada, K.; Hirano, S.; Himeno, Y.; Shibata, K.; Kawano, K.; Kitano, S. Optimal management of the branch duct type intraductal papillary mucinous neoplasms of the pancreas. J. Clin. Gastroenterol. 2003, 36, 261-265. [CrossRef] [PubMed]

52. Sugiyama, M.; Izumisato, Y.; Abe, N.; Masaki, T.; Mori, T.; Atomi, Y. Predictive factors for malignancy in intraductal papillary-mucinous tumours of the pancreas. Br. J. Surg. 2003, 90, 1244-1249. [CrossRef]

53. Walsh, R.M.; Vogt, D.P.; Henderson, J.M.; Hirose, K.; Mason, T.; Bencsath, K.; Hammel, J.; Brown, N. Management of suspected pancreatic cystic neoplasms based on cyst size. Surgery 2008, 144, 677-684. [CrossRef] [PubMed]

54. Weinberg, B.M.; Spiegel, B.M.; Tomlinson, J.S.; Farrell, J.J. Asymptomatic pancreatic cystic neoplasms: Maximizing survival and quality of life using Markov-based clinical nomograms. Gastroenterology 2010, 138, 531-540. [CrossRef] [PubMed]

55. Jang, J.Y.; Kim, S.W.; Lee, S.E.; Yang, S.H.; Lee, K.U.; Lee, Y.J.; Kim, S.C.; Han, D.J.; Choi, D.W.; Choi, S.H.; et al. Treatment guidelines for branch duct type intraductal papillary mucinous neoplasms of the pancreas: When can we operate or observe? Ann. Surg. Oncol. 2008, 15, 199-205. [CrossRef]

56. Tanaka, M. Controversies in the management of pancreatic IPMN. Nat. Rev. Gastroenterol. Hepatol. 2011, 8 , 56-60. [CrossRef] [PubMed] 
57. Scheiman, J.M.; Hwang, J.H.; Moayyedi, P. American gastroenterological association technical review on the diagnosis and management of asymptomatic neoplastic pancreatic cysts. Gastroenterology 2015, 148, 824-848, e822. [CrossRef]

58. Uehara, H.; Ishikawa, O.; Katayama, K.; Kawada, N.; Ikezawa, K.; Fukutake, N.; Takakura, R.; Takano, Y.; Tanaka, S.; Takenaka, A. Size of mural nodule as an indicator of surgery for branch duct intraductal papillary mucinous neoplasm of the pancreas during follow-up. J. Gastroenterol. 2011, 46, 657-663. [CrossRef]

59. Marchegiani, G.; Andrianello, S.; Borin, A.; Dal Borgo, C.; Perri, G.; Pollini, T.; Romano, G.; D'Onofrio, M.; Gabbrielli, A.; Scarpa, A.; et al. Systematic review, meta-analysis, and a high-volume center experience supporting the new role of mural nodules proposed by the updated 2017 international guidelines on IPMN of the pancreas. Surgery 2018, 163, 1272-1279. [CrossRef]

60. Ohno, E.; Hirooka, Y.; Itoh, A.; Ishigami, M.; Katano, Y.; Ohmiya, N.; Niwa, Y.; Goto, H. Intraductal papillary mucinous neoplasms of the pancreas: Differentiation of malignant and benign tumors by endoscopic ultrasound findings of mural nodules. Ann. Surg. 2009, 249, 628-634. [CrossRef]

61. Kawada, N.; Uehara, H.; Nagata, S.; Tsuchishima, M.; Tsutsumi, M.; Tomita, Y. Mural nodule of $10 \mathrm{~mm}$ or larger as predictor of malignancy for intraductal papillary mucinous neoplasm of the pancreas: Pathological and radiological evaluations. Pancreatology 2016, 16, 441-448. [CrossRef]

62. Moher, D.; Liberati, A.; Tetzlaff, J.; Altman, D.G.; Group, P. Preferred reporting items for systematic reviews and meta-analyses: The PRISMA statement. BMJ 2009, 339, b2535. [CrossRef]

63. Higgins, J.P.T.; Thomas, J.; Chandler, J.; Cumpston, M.; Li, T.; Page, M.J.; Welch, V.A. Cochrane Handbook for Systematic Reviews of Interventions, version 6.0 (updated July 2019); Cochrane: London, UK, 2019; Available online: www.training.cochrane.org/handbook (accessed on 20 July 2020).

64. Stroup, D.F.; Berlin, J.A.; Morton, S.C.; Olkin, I.; Williamson, G.D.; Rennie, D.; Moher, D.; Becker, B.J.; Sipe, T.A.; Thacker, S.B. Meta-analysis of observational studies in epidemiology: A proposal for reporting. Meta-analysis Of Observational Studies in Epidemiology (MOOSE) group. JAMA 2000, 283, 2008-2012. [CrossRef]

(C) 2020 by the authors. Licensee MDPI, Basel, Switzerland. This article is an open access article distributed under the terms and conditions of the Creative Commons Attribution (CC BY) license (http://creativecommons.org/licenses/by/4.0/). 